\title{
ENPP2 Gene
}

National Cancer Institute

\section{Source}

National Cancer Institute. ENPP2 Gene. NCI Thesaurus. Code C104209.

This gene plays a role in the hydrolysis of lysophospholipids. 